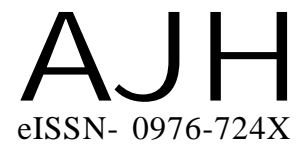

Received : 01.12.2015

Revised : 08.04.2016

Accepted : 21.04.2016

Members of the Research Forum

Associated Authors:

College of Horticulture, Dr.

Panjabrao Deshmukh Krishi

Vidyapeeth, AKOLA (M.S.) INDIA

Author for correspondence :

SURENDRA R. PATIL

College of Horticulture, Dr.

Panjabrao Deshmukh Krishi

Vidyapeeth, AKOLA (M.S.) INDIA

Email : srpatil1812@rediffmail.com
THEASIAN JOURNALOF HORTICULTURE

Volume 11 | Issue 1 | June, 2016 | 36-39

Visit us -www.researchjournal.co.in

RESEARCH PAPER

DOI : 10.15740/HAS/TAJH/11.1/36-39

\title{
Effect of biofertilizers on growth of Rangpur lime seedlings
}

\section{SANGITA S. WANKHEDE ${ }^{1}$, SURENDRA R. PATIL AND ARVIND M. SONKAMBLE ${ }^{1}$}

ABSTRACT : The pot culture experiment was conducted to study the effect of biofertilizers on growth of the Rangpur lime seedlings. There were eleven treatments of inoculation of Glomus fasciculatum (50g and 100g), Glomus mosseae (50g and 100g), PSB $3 \mathrm{~g}$ and Neem cake $20 \mathrm{~g}$ per seedling of Rangpur lime and its combination were given at the time of transplanting of Rangpur lime seedling in polythene bags and replicated trice. The experiment was laid out in Completely Ranzomized Design. The growth of Rangpur lime seedlings i.e. seedling height, stem diameter, number of leaves, leaf area, root growth, biomass accumulation, bud take percentage and final survival were found significantly superior under treatment $G m-50 \mathrm{~g}+G f-50 \mathrm{~g}+\mathrm{PSB}-3 \mathrm{~g}$ and $G f$ $50 \mathrm{~g}+$ PSB $-3 \mathrm{~g}+$ Neem cake $20 \mathrm{~g}$ per pot against rest of the treatments.

KEY WORDS : Rangpur lime, Mycorrhiza, Neem cake, PSB

HOW TO CITE THIS ARTICLE : Wankhede, Sangita S., Patil, Surendra R. and Sonkamble, Arvind M. (2016). Effect of biofertilizers on growth of Rangpur lime seedlings. Asian J. Hort., 11(1) : 36-39, DOI : 10.15740/HAS/TAJH/11.1/36-39. 